\title{
Exotic/Other: Narratives of Muslims, the Role of Media and Popular Culture *
}

\author{
Khalida Tanvir Syed, \\ Visiting Scholar, St. Paul's College, University of Manitoba \\ ksyed@ualberta.ca
}

"Otherness, yes. But are we not always prey to otherness? .... All the time. The world is mistaken. It imagines that the other takes something from us whereas the other only brings to us, all the time. The other is complex. He can be our enemy and our friend."

(Cixous, H. \& Calle-Gruber, M. p. 13, 1997)

\begin{abstract}
This commentary paper explores experiences of Muslims being identified as an exotic/other by the media after September 11, 2001. The writer's experience of being chosen for attention because of her Muslim female dress code, headscarf, during a National Aboriginal Day of Action, was a surprise for her. Instead of paying attention to the event, a media reporter questioned "why I covered". This narrative introduces a poignant awareness of the power of media to make choices that identify and define the exotic/other. Narratives of another Muslim woman and two Muslim men illustrate the role of the media and popular culture to form and represent identities. The purpose of this commentary is to show how, in becoming aware of how we as individuals and the media in our culture, in the post $9-11$ society, are reacting, choosing, refusing, and accepting the making of our identities.
\end{abstract}

\section{Introduction}

Since the dramatic events of September $11^{\text {th }}, 2001$, and the ensuing 'war' on terror, Muslim culture has gained an unprecedented level of negative attention in Western media. Though Muslims have a long and peaceful history in North American culture, they have recently been portrayed as 'others' with 'exotic' habits.

Recently, I attended a protest at the Alberta Legislature in support of the National Aboriginal Day of Action. The event was attended not only by aboriginal protesters, but also by University of Alberta students and professors, provincial government Members of the Legislative Assembly and city counselors. I went to the protest with a white female university colleague and her husband, who is of Metis ancestry. After the speeches and demonstration, I helped the organizers, who I knew through academic networks, to clean up their display table and protest banners and placards. I was pleased when a television cameraman approached me, thinking that he was interested in hearing my perspective on the native issues that had been the focus of the demonstration. To my surprise, however, he greeted me with "If you don't mind, could I interview you about why you cover?" 
This question took me off guard for two reasons. Firstly, it was irrelevant to the event, and I took his question as an insult to the importance of the National Aboriginal Day of Action. Secondly, the question presumed that I was dressing as I did for political reasons, and the reporter took my appearance as an 'exotic' topic that would guarantee coverage on the evening news. People, nowadays, are interested to know about 'mysterious' Muslim women, what do they do and think under those hijabs - headscarves?

Though I do cover, I wasn't wearing traditional dress or a face covering veil or burka. I wore a hijab (headscarf), a thigh length, light khaki top over casual pants and a tshirt, suitable clothing for a summer afternoon. It was a hot day, and many of the other protesters took the opportunity to wade or bathe in a pool located in front of the Alberta legislature stairs. I had earlier looked at some of the women in the pool, playing in bikini tops in front of their government buildings, and some of the protesters standing beside me, who wore tops that exposed their pierced belly buttons. Though I was born and raised in Pakistan, I have lived and studied in Canada for nearly eighteen years. Obviously, I have become accustomed to Western women's mode of dress. The fact, however, that their exposed bodies were less interesting than my headscarf to the reporter embodies, to me, the strange position that Muslims have in Popular Western Culture. My reply to the reporter was this, "Please turn off your camera. If you'd like to interview me, would you please first ask those girls," I pointed to a couple wading in the pool, "why they have chosen to uncover?"

In my heart I was wondered, reminded of Cixous and Calle-Gruber (1997), "How can we see what we no longer see?" (p. 4). The Western women's' mode of dress was so familiar to the reporter that he no longer curious or interested in it, despite the fact that their dress differed from his own full sleeves dress shirt and trousers. I explained to the reporter that, as a Muslim woman, I was interested to know why these Western women chose to dress the way that they did. He was shocked by the idea of questioning them. It would be wildly inappropriate and rude for a white, Western professional male to ask Western women why they were dressed skimpily in front of a television camera. When Muslim women are seen as 'exotic/others,' however, it becomes suddenly appropriate to interrogate their clothing choices. As the 'other' I was also poignantly aware of how the contrast between my clothing and the other women's' defined me in the eyes of the reporter. And yet, is this not how we are all defined: "The other in all his or her forms gives me I. It is on the occasion of the other that I catch sight of me; or that I catch me at: reacting, choosing, refusing, accepting. It is the other who makes my portrait" (Cixous \& Calle-Gruber, 1997, p. 13).

This event and similar incidents of cultural contrast have driven home to me the fact that I am viewed as external to the media and popular culture in which I live and study in Canada. If Popular Culture is to gain a true, rather than 'exotic' or incendiary view of North American Muslims, however, I feel that it is vitally important to have media dialogue that moves in two directions. My comment to the reporter was not wholly facetious. The educational theorist Toelken (1976) viewed cultural education as an important component of harmonious social interaction: "how differently we see things, envision things, and look at things, how dissimilarly different cultures try to process the world of reality" (p. 10). In modern culture, media is commonly the vector of cultural learning, rather than first-hand intercultural experiences. Media 'teaches' us how to see 
the world, framing our perceptions of 'other.' This is why I balked at the interview, reluctant to portray myself as a cultural 'exotic other'.

This narrative introduces a poignant awareness of the power of media to make choices that identify and define the "exotic/other". The purpose of this commentary is to show how, in becoming aware of how we as individuals and the media in our culture, in the post $9-11$ society, are reacting, choosing, refusing, and accepting the making of our identities. An historical context will be provided first. The role of media and popular culture will be considered next, followed by the narratives of another Muslim woman, reporter Yvonne Ridley, and of two Muslim men to illustrate the role of the media and popular culture to form and represent identities.

\section{Historical cultural context of Muslims in North America}

Far from being a recently acquired cultural minority, Muslims have had an enduring presence in Canada and the United States since the early 1900's (Abu-Laban, 1980; Abu-Laban \& McIrvin, 1991). A surge of immigration to Eastern North America between 1945 and 1967 occurred in response to political upheaval in middle-East and South Asia (Haddad, 1978). Today, Statistics Canada reports that immigration of Arab Muslims is increasing. Historically, Canadian immigration policies were not only based on a quota system, but also on how closely the prospective immigrants ranked in racial, cultural, and linguistic similarities to the British Protestant ideal (Haddad, 1978). Before 1967, most Muslim immigrants came from Lebanon, Syria, Palestine, and Jordan, and many were 'non-visible' in Western culture because of their light skin tone. These immigrants also came from upper-middle classes and were educated professionals who found work readily after immigration. Since 1967, immigration policies have shifted from a 'quota' to a 'points' system (Abu-Laban, 1980), with increasing admittance of darkskinned brown or black Muslims from Africa and the South Asia, who were usually educated for skilled labour. The stereotypical dark-skinned Muslim taxi-driver embodies Popular Cultural perception of these more recent immigrants. In the last twenty years, there has been a $122 \%$ increase in Canadian census reportage of Islamic faith. A visibly distinct large group gain the status of 'exotic/other,' particularly after the events of September $11^{\text {th, }} 2001$ brought media attention.

\section{Exotic/other: Media and the popular culture}

According to Steinberg (2001), dominant cultures usually do not promote free speech, they wouldn't allow critical interpretation of history, and do not, under any circumstances, want educational institutions to create a place for the marginalized in society. Modern media portrayals of Muslims are commonly saturated by vestiges of colonial Orientalist mythology (Said, 1993). The Orient or Eastern Cultures were, to Western colonial eyes, not just different, but 'oddly' different - in the event where the Occident could have rationality, some sensibility and familiar, then East was the opposite of all of that.

At this stage, I would like to address some questions to my participants. Imagine that you have seen, heard, and interacted with a Muslim. When you see or hear the word 
Muslim, what first comes into your mind? What are the images you already have in your head from the media?

Now, wait! Don't tell me: let me guess what you are imagining. If the image is a Muslim woman, I am sure, definitely, that you are imagining a suppressed or oppressed woman covering her own body. You may think I am marginalized, maybe you pity me. But I believe that I am blessed, not oppressed or suppressed. I feel that my body is not an object, open for free gazing, and I choose to cover it because I feel that covering is for my own protection as you wear a seat-belt in a car for your safety and the safety of others. I am proud of being Muslim. Islam gave me women's rights 1400 years ago, when the Prophet Mohammed's wife worked as a business woman, and the Prophet Mohammed was her employee. Did you know that?

While contemporary rules of Western classification, social structure and social hierarchies are difficult for Western media to describe, because 'it operates within the rules and they are taken for granted', aspects of Eastern (and Indigenous) cultures are 'revealed' by their difference to Western rules, and considered worthy of public attention. While the head coverings of Muslim women have been thoroughly critiqued by the media, and repeatedly presented as a sign of oppression in the media, the recent trials of two North American Muslim men demonstrate a more malign bias in Western culture. This paper retells the stories of American Muslim Jose Solis Jordan and Canadian Muslim Maher Arrar, discussing the impact of media interest and/or disinterest on Western Popular perception of North American Muslims. To begin, however, I would like to introduce a third character, journalist Yvone Ridley.

\section{Yvonne - from the outside in}

Yvonne Ridley is a British Muslim, but unlike born Muslims who are raised within communities of faith, she converted after a unique period of exposure to Muslim culture in the hands of the Taleban in Afghanistan. Working as an international journalist, Yvonne was captured by the Taleban while working undercover in Afghanistan, and as released after ten days on the condition that she promise to study the Quran. Contrary to the expectation of many of her colleagues, Yvonne embraced Islam and has become a staunch advocate for women's rights and a founding member of the Friends of Islam in Britain. Before her kidnapping, Yvonne admits that she saw Muslims, particularly women, as exotic and oppressed others: "I used to look at [other] veiled women as quiet, oppressed creatures and now I look at them as multi-skilled, multi-talented, resilient women whose brand of sisterhood makes the western feminism pale" (Ridley, 2006). Her opinion, and perception of Muslim women shifted as first-hand experience studying the Quran and meeting practicing Muslim women who chose to cover, even in the West, replaced a media-provided stereotype. "Young feminist Muslimahs see the hijab and the nikab as political symbols as well as a religious requirement. Some say it is their way of showing the world they reject the excesses of Western lifestyles such as binge drinking, casual sex, drug-taking etc" (Ridley, 2006).

As a reporter, Yvonne Ridley committed to studying the Quran when she realized that the professionalism of her reporting required that she overcome stereotypes and gain a deeper understanding of the cultures which she was reporting on. Ridley (2006) writes: 
Reading the Quran was, I thought, going to be a very simple academic exercise. I was stunned to discover that it clearly stated women are equal in spirituality, education and worth. A woman's gift for child birth and child-rearing is very much recognised as a quality and attribute. Muslim women say with pride they are homemakers and housewives (Ridley, 2006).

As a feminist, Yvonne found resonance with these teachings, and with the Muslim women's' rights movements. As a reporter, she was again surprised to discover the ways in which Islamic communities may regard Western concerns as 'exotic' or 'odd': 'Isn't it funny the way the tabloid media gets very excited over the prospect of some pop or film stars pre-nuptial wedding agreement? Muslim women have had wedding contracts from day one" (Ridley, 2006). In Western countries, Muslim perspectives are given little voice in the media, and what air-time Muslims do receive is usually taken up with interview questions surrounding their 'otherness'. Yvonne considers this 'Islamophobia' to be "the last refuge of the racist scoundrel" (Ridley, 2006). A last opportunity for Western superiority and cultural oppression and stereotyping.

Returning to the focus of this paper on the experiences of Muslims within Western Popular culture, I will explore the effects of biased media exposure in the cases of Jose Solis Jordan and Maher Arrar.

\section{Jose's story - embracing the Exotic/other}

In this section, I share the narrative of North American white non-Muslim educators Kincheloe, Steinberg and McLaren's experiences with Jose Solis Jordan, a brown Muslim activist and educator who was sentenced for sedition in the United States. These narratives appear in the book Multi/Intercultural Conversations, whose authors intend both to reveal Jose's story, and to set an example of how academics can make a difference, by standing up for justice to preserve the diverse and discursively intermeshed realities of multi-based interculturalism.

Before presenting the authors' narratives, you may be wondering, who is Jose? Before reading this book, I had not heard of him either, as his case was silent in the media. Jose is an education scholar who taught at De Paul University and the Universities of Puerto Rico and Chicago. As a brown, Puerto Rican Muslim, Jose has always spoke for those who were subjected to police violence, which serves a system that maintains the interests of dominant groups in the population. What makes him dangerous to the Western 'rules' is his "human praxis" that is "self-reflexive and dialectical" (p. 629). He was jailed as a political prisoner in 2001, on charges brought forth by agents of the Federal Bureau of Investigation (FBI). He became subject of investigation through his political activism on behalf of freedom of speech and democracy, and for statements made at De Paul University, Chicago, regarding the motives behind the American invasions of Iraq and Afghanistan after September $11^{\text {th }}$. What Jose considered to be 'critical pedagogy' was viewed by the FBI as incendiary sedition. Jose served a sentence of three years in prison, becoming a symbol to his academic colleagues of the struggle against United States (US) imperialism (McLaren, 2001).

In a country like the US, where freedom of speech is touted as a social right, Jose's trial and jail term are a shocking violation of human rights. While news reporters were interviewing Muslim women on their so-called oppressive accruements, the media 
completely overlooked Jose's experiences of oppression, and its effect on the Muslim and Puerto Rican communities in Chicago. Jose's story has only come into print through the efforts of the writers/educators Steinberg and Kinchloe, who are neither Muslims nor visible minorities. As white educators, representative of dominant North American culture, they rejected the US's silent narrative of oppression, and took up positions at McGill University in Canada.

Media, according to Said (1993), has the power to brainwash the population and create stereotyped images of 'otherness.' McLaren, Steinberg and Kinchloe saw beyond the media's portrayal of Western Muslims, largely through their critical social stance and personal interactions with Jose, which provided an opportunity for them to view the reality of his situation through a different lens. Steinberg (2001) notes that "As devout Msulims, [Jose and his wife] have had to negotiate life in the very Jewish/Waspish New York. Our friend-ship with them includes many conversations on my Jewishness, Joes' Tennessee Universalism, and [their] devout view of Islam (p. XXVIII)." By taking initiative to overcome differences of perception, Kinchloe, Stienberg and McLeran have become role models for the academic community on how to break cultural oppression enforced by Popular culture and media. Their narratives prove that unbiased friendship can cross the boundaries that usually enforce the us-them binary.

Beginning his narrative, Kinchloe wrote the following poem to his friend:

To Jose

The living embodiment of the abstract issues we babble about. the stark representation of the price to be paid. out of place in the land of the free.

it's better you be swept under the rug so as not to disturb lives of privilege.

the fire of your passion, however, cannot be contained and you send piercing reminders from the belly of the beast.

you transmogrify into our raison d'être you recharge our soul.

help us share your pain

and humbly evolve in the process.

Tomorrow - bring it on. (by the late Joe Kincheloe)

Kinchloe wrote a very caring and encouraging poem to his friend, to tell him that he is not alone. One of the lines which I find most inspiring is the plea that Jose's story will help us to 'humbly evolve' in our perspectives, our biases, and the actions they inform. Kinchloe's friendship with Jose Solis Jordan is an example for me of how to see positive qualities in others, despite the fact that they are not Muslim themselves. It is important to note that Kinchloe is Christian, and his wife and collaborator Steinberg is Jewish. It required both courage, and time-consuming academic commitments, to bring Jose's story forward in book form. Further, they dedicated their book, Multi/Intercultural Conversations, and all its royalties to Jose's wife Martha and their children. Their friendship and collegial support moved beyond boundaries, and their multicultural 
education and pedagogy helped them to give voice to a prisoner corned into one of the most impotent and marginal of social positions.

Jose's story brings to mind educational theorist Paulo Freire, another revolutionary, who's writing helped Steinberg to realize: "how to read the world from different plains, different eyes and to know that there are always so many more that have so many more needs than I could ever imagine" (2001, p. xxix). Steinberg, Kinchloe and McLaren have, in turn, taught me to read the world through different lenses, reject stereo-typing, and try to make sense of my own understanding of otherness. Islam teaches me that cultural education means not only standing up for your own group (for example, colour, religion, culture, geography, language, etc,), but standing up for social justice for all human beings. It was in the spirit of this lesson that I went with my friends to stand up for the rights of Canadian Aboriginal People. I was gaining no personal benefit from attending the rally, and was certainly not there to steal the media spotlight for a discussion of Muslim head coverings. The organizer of the rally, a fellow graduate student in my department, thanked me for attending and for my efforts to contribute to their cause.

Perhaps the best expression of thanks for intercultural support comes from Jose himself. In response to Kinchloe's poem, he wrote the following:

As long as the pain is unheard;

\section{A Few Lines}

As long as our sense of shame and indignation, amidst the injustice, is excused by our indifference; as long as education is expressed as a rationalization of our own fear to give life to the word - liberation, we will remain imprisoned, because prison is ultimately the denial of our own commitment to our own humanity.

And so, today they can lie because the pain has

become numbing.

today they can silence because the indifference

has become deafening.

today they can rationalize because the fear has become natural.

But, they can't stop tomorrow.

$[\ldots]$

Take care my friends.

Working in International education, I have read many heart-rending discourses on cultural and social injustice. Still, I found myself approaching tears as I read Jose's second stanza, especially: "today they can silence because the indifference, has become deafening." Today, when there is silence or indifference, it is usually because a topic has not 'earned' public attention through the conscience of the media.

\section{Maher Arrar - a ray of hope}

From Yvone and Jose's stories we catch a glimmer of how intercultural dialogue can pave the way for respectful relationships, and unbiased coverage in media, be it television journalism or an academic text. The recent case of Maher Arrar provides a 
hopeful, though tragic, example of how sensitive and culturally responsible media coverage can act for social justice. It has been said, in many ways, that knowledge can overcome fear. We are afraid of what we are ignorant of, and support what we know, or feel empathy with. Like Kinchole, McLaren and Steinberg, the Canadian public recently became acquainted with Maher Arrar through media coverage that, by fair portrayal of events, evoked great public sympathy and outrage. In his book, Pedagogy of the Oppressed (1970), Paulo Freire stresses the value of conscientizacao--a state of consciousness of "social, political and economic contradictions and the need for action against the oppressive elements of reality" (p. 35). Media coverage of Maher Arrar's case provides an example of conscientizacao, which encourage me to believe in a future where cultural stereotyping will no longer pave the way for social injustices.

What happened in the Mahar Arrar's case? For those of you who did not follow the media coverage, I will provide a brief synopsis. Mahar was a 34 year old computer engineer who, though born in Syria, had resided in Canada since the age of 17, and had gained Canadian Citizenship in 1991. September $26^{\text {th }}, 2002$, he was arrested and detained by United States officials on the basis of alleged links to the al-Qaeda network. After twelve days of imprisonment, Maher was shackled and relocated to a tiny "grave-like" cell in Syria, where he was held without legal representation for ten months, and repeatedly beaten and tortured to elicit false confessions. No one know why he was sent to Syria, however, he was citizen of Canada. Maher's wife, Monia, brought media attention to her husband's plight until he was returned to Canada in October, 2003.

Monia was relentless in gaining attention, not only from the media but from human rights organizations and a large number of unaffiliated Canadians, who jointly pressured the Government of Canada into initiating a formal inquiry into Maher Arrar's unjust treatment. Between January $28^{\text {th }}, 2004$, and September $18^{\text {th }}, 2006$, the Inquiry found no evidence against Maher Arrar, but did isolate problems and inconsistencies in Canada and the US's justice programs. Justice Dennis O'Connor, who Commissioned the Inquiry stated that "categorically that there is no evidence to indicate that Mr. Arrar has committed any offence or that his activities constitute a threat to the security of Canada" (Sep, 18 $\left.{ }^{\text {th }}, 2006\right)$. Media's involvement in Maher Arrar's case pressured the government and political leaders to be accountable for injustices perpetrated upon their citizens. Theoretically, all North Americans are protected by human rights, but in practice, these rights are unrealized and misuse of power by policing bodies and secret government agencies undermines the rights of citizens. It is interesting, comparing the cases of Maher and Jose, to note that, though Jose was accused merely of sedition, not terrorist collaboration, he served a complete sentence and receive little media sympathy. Is this a difference between Canada and the United States, I think not. I think it is a difference between the decision of the media to ignore Jose's circumstances and to sympathize and aggrandize Maher Arrar. When stories of injustice are made public, it is much more difficult for the powerful to escape accountability. Recalling Jose's poem, A Few Lines, the volume of indignance is vital to the correction of injustice: "As long as the pain is unheard..." we are "excused by our indifference." The public cannot, however, be expected to keep pace of injustices which they never hear about. Biased or incomplete media coverage, can, thus, undermine the social integrity of our societies. 


\section{Conclusion: Seeing from both sides}

"Equality is like gravity: we need it to stand on this earth." Joss Wheedon

I began by explaining the circumstances under which my head scarf nearly made it to the evening news - I was supporting the cause of Aboriginal rights in Canada. I was there not because I am aboriginal but because they are a part of the society in which I live and work, and injustices perpetrated upon them are perpetrated upon all of us. To be honest, we all recognize 'others' in our societies, but when we ignore or remain willfully ignorant of them, we do a disservice not only to them, but also to ourselves. Cixous and CalleGruber (1997) remind us that when we 'come down on one side - we cut out a part of ourself.' The other is in me and I am in the other, we define each other and cannot define ourselves fully if we are not willing to initiate dialogue.

I will invite you (readers) enter into a dialogue where we can stand together to raise a voice against systemic injustice. This discussion may lead us to find a way as educators to serve humanity without any racial, religious, geographical, cultural, ethnic, or linguistic barriers in culturally diverse classroom settings. Their stories, their examples, their ways of helping a friend, are unique, and I think that it is education that teaches us to make sense on our own, instead of blindly following the media. I think they are real educators who not only have wisdom to make their own reality but also courage to stand up for social justice. Non-Muslims raise their voices for Jose and Mahar and use their abilities to show the world with their example to give hope and care to the most marginalized in Jail.

By sharing these narratives, I hope, like Steinberg, Kinchloe, and McLaren narratives may encourage us to stand up as educators and make a commitment to forming unbiased relationships with the marginalized other, so that at the end of the day, we all respect and love each other, and bring harmony and peace through our actions, to the real world. 


\section{References}

Abu-Laban, B. (1980). An olive branch on the family tree: The Arabs in Canada. Toronto: McClelland and Stewart Ltd. in association with the Multiculturalism Directorate, Dept. of the Secretary of State and the Canadian Government Publishing Centre, Supply and Services Canada.

Abu-Laban, S. \& McIrvin, S. (1991). Family and religion among Muslim immigrants and their decedents. In E. Waugh, S. McIrvin, S. Abu-Laban \& B. Qureshi (Eds.), Muslim families in North America. Edmonton: University of Alberta Press.

Cixous, H. \& Calle-Gruber, M. (1997). Rootprints: Memory and life writing. Ruthledge: London and NewYork.

Freire, P. (1970). Pedagogy of the oppressed. New York: Continuum.

Haddad, Y. (1978). Muslims in Canada: a Preliminary Study. In H. Coward \& L. Kawamura (Eds.), Religion and ethnicity: essays. Waterloo, Ont.: Calgary Institute for Humanities by Wilfred Laurier University Press.

Kincheloe, J.L. \& Steinberg, S.R. (1997). Changing multi/interculturalism. Philadelphia, PA: Open University Press.

MaherArar. (2012). Maher's story in brief. Retrieved from http://www.maherarar.net/

Ridley, Y. (2006). http://www.yvonneridley.org/article.php?id=54

Said, E. W. (1993). Culture and imperialism. New York: Alfred A. Knopf.

Toelken, B. (1976). Seeing with the native eye: How many sheep will it hold? In W. H. Capps (Ed.), Seeing with the native eye: Essays on Native American religion (pp .9-24). New York: Harper \& Row. 